者の $4 \%$ に当り，女子は 1 名に過ぎない。類别すると， 第 1 色覚暴常 13 名, 第 2 色覚異常 263 名で色覚暴常の大 部分を占め，全色盲は 5 名であった。これらの色覚異労 者は大半，終戦禾期前後に入社した者に多い。

3. 主要照疾患について：有疾者数 419 名で総受検者 の約 $6 \%$ にあたり，病類别にみると，高血王性眼底 279 名 $(67 \%)$ で意外に多く, 最高位を示し, ついで外腿部 疾患, トラューマ, 網・脉絡膜疾患, 透光体疾患, 視力 疾患の順位であった。

4. 高血压性眼底について：全身简血压者 1114 名で 高血王性眼底所見のあるもの329 名，ないもの787名で あり，高齢者ならでに全身高血压者であるほど腿底に変 化を認めるものが多い。KW 分類についても同様な傾 向がタらられた。高血圧性眼底の腿底所見亡全身血压值と の関係は必らずしも並行的でなく，正常血王值を示した ものが $0.17 \%$ あった。

\section{0. 某工場從業員の視力障害に関する調查}

中野 雪 (宇部興産宇部窒素䛦療所)

大不省三（山口罢立医大限科）

某化学工場の従業員 2700 名について，1眼でも矯正 視力の 0.7 に澾しない者 171 名を選び出し, 統計的観察 を試みた。

視力の矯正されない主なる原因が屈折買常によると思 われる者 90 名 $(52.6 \%)$ で最も多く, その5ち近視（近 視性乱視を含む) 58 名, 遠視（遠乱を含む）38名, 雑性 乱視 4 名。つぎに眼底疾患によるもの 25 名，らちわけは 中心性網膜炎 14 名，脈絡膜炎 3 名，高血王性絧膜症 3 名 視束炎 3 名，脚気弱視 1 名，硝子体動脈遺残 1 名であ る。前眼部疾患は角膜混濁 18 名, トラコーマパンスス 3 名計21名。そのほ加白内障 4 名, 眼振 1 名。

これらの人々の過去 5 年間に年 2 回行なわれた検診成 續（裸腿視力を主として）を経過を和って見ると，342 眼の中で視力が不変のもの 125 腿, 低下したもの97眼, 視力が上昇したもの 120 腿である。

著るしく視力の動摇のあったものは11眼で, 中心性網 膜炎 5 眼, 角膜障害 3 眼, 遠視 2 眼, 朣孔不同症 1 眼で ある。

視力障害の程度は 342 眼中, 矯正視加が 0.7 に達しな いもの 278 眼である。 0.7 は 31 眼，0.6 は42眼，0.5 40 眼, $0.4^{\top}$ は 28 眼, 0.3 は41眼, 0.2 は26眼, 0.1 は3 眼，指数弁 27 眼である。

以上，視才障害は直接工場災害によるものはきわめて 少なく，原因は入社当初から艺の状態にあったものが大
半であり，検診時摫力の多少の動摇はまぬがれないとし ても, 視力の後天的低下の原因に中心性網膜炎の占める. 地位がかなり大きいことを知った。

\section{1. 神奈川県下事業場の衛生管理活動}

山本秀夫，西岡宣子（神奈川労働基準局）

真下の大企籍に扣ける労衝衛生管理活動が活発である ことは御承知のことであろらが，衛生週間を機に調查し た中小規模重㸁埸に拈ける活動の実態について報皆し た。

1. 対象：主要策種 740 事業場

2. 調查者：基準屏学働衛生課及び各監督署職員

3. 時期：昭和35年 9 月16日より10月 7 日

4. 絈果：

1）有㫪業務管理：イ. 施設改善状況 口. 環境測定 八. 保護具の倩付, 管理, 使用二。特殊健康彭断 実施 ホ。その仿

2) 管理体制：イ。医師衛生管理者（尃任, 非専任） 口. 非医師衛生管理者（専任, 非専任）の選任状況 八. 末端組織の確立 二. 衛生委員会 ホ. 管理年 報，記録，統計

3) 活動：个. 衛生教育（雇入時, 有害作業者, 末端 青任者，救急訓練）口。健康相談（担当者，回 数）八. 多発疾患対策（肺結核，感冒性及び胃腸 疾患）二. 成人病刘策 木. 夏期, 疲労, 食中毒 対策

4) その他

たとえば衛生教育は労衝衛生管理上きわめて重要なも のであるが，規則に基く雁い入れ時のものでも，50人以 下ではわずかに $17.7 \%$ ，300 人以上の大企業でも $86 \%$ にとどまっている。とくに有害栄務につくものに対して は常時教育が必要である沈もかかわらず，大企業でも 30\% 強の未実施があり，小企等にいたっては 10\%を割 る始末である。救急訓練についてはさらにひどい実情で ある。

進えでいると又られる当罢でも，中小企業はこのよら な実態であった。学衝衛生水準の向上には多大の努力を 要する。

\section{2. 商店員の保健管理に関する基礎資料（I）}

方波見雅夫（北海道労研） 高桑 栄松（北大 衛生）

中小企業従業員の健康管理については, わが国産業労 働の三重構造的性格からみて，大企㧘のそれとは異なっ 